\title{
キトサンコーティングしたセロファンフィルムの性質
}

\author{
四国工業技術試験所 細川純・吉原 一年・西山 昌史 \\ 新興人化成株式会社 綱 島 肇*.森本 㑆 ${ }^{*}$
}

\section{PROPERTIES OF CELLOPHANE FILMS COATED WITH CHITOSAN}

\author{
Jun Hosokawa ${ }^{* 1}$, Hajime Tsunashima ${ }^{* 2}$, Kazutoshi Yoshihara*1, \\ Masashi Nishiyama*1, and Sunao Morimoto ${ }^{* 2}$
}

*1 Government Industrial Research Institute Shikoku, 2-3-3 Hananomiya-cho, Takamatsu, 761 Japan

*2 Shinkohjin Kasei Co., Ltd., 1-1 Kohkoku-cho, Yatsushiro-shi, Kumamoto, 866 Japan

\begin{abstract}
Coating of chitosan on cellophane was studied with the aim of giving new functional properties to cellophane film. The transparency and the water vapor transmission rate of cellophane were not lowered by the chitosan coating on cellophane. The adhesive strength between cellophane and chitosan layers was very high, and increased with the chitosan concentration of the coating layer at the alkali-treat. ment stage. The adhesive strength of $170 \mathrm{kgf} / \mathrm{cm}^{2}$ was obtained when the chitosan concentration of the coating layer was $90 \%$. Chitosan coating was not so effective in improving tensile and tearing strengths of cellophane. The chitosan layer readily absorbed silver ions, and the coating film bearing silver had anti. bacterial action against four pathogenic bacteria, namely Escherichia coli, Salmonella typhimurium, Vibrio parahaemolyticus, and Staphylococcus aureus. Silver of $1500 \mathrm{ppm}$ in the coating film was sufficient to prevent the propagation of the bacteria, while the coating film without silver did not have the discernible antibacterial action.
\end{abstract}

(Received June 21, 1991)

\section{1. 粕 言}

セロファンは透明性が高く透湿性のあるフィルムとし て，現在包装用などに用いられているが，新しい機能を 付加し難い素材である。一方, キトサンは透過膜 [1], 良染色性〔2]，医用材料〔3]など，種々の機能を発現で きる素材であるが，包装用フィルムの素材として用いる には高価である。そこでセロファン上にキトサンをコー ティングして，両者の特長を生かしながら新しい機能を 付与することを考えた。

レーヨン等の樴維にキトサンをコーティングし，良染 色能を付与する試みについては Allan and Hirabayashi (4)が既に報告している。しかし、フィルムへのコーテ イングの場合，透明度などセロファン自身の特長を損な わず，剩離し難いキトサンコート畨ができるようなコー
ティング法を調ベる必要がある。また,コーティンタさ れたセロファンに，良染色能以外にもどのような椎能を 付与できるか検討することも必要である。

そこで，我々はセロファンへのキトサンコーティンタ 条件を検傠した。また，得られたコーティングフィルム の機能付与として食中毒菌に対する抗菌性の包装用フィ ルムを考え、コーティング層への銀の吸着と抗菌性:に いて検討を行ったので報告する。

\section{2. 実鑍}

\section{1 試 料}

キトサンは(株)加ト吉製の海老凯由来キトサン10日

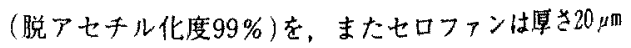
の市販セロファンフィルムを用いた。

\section{2 コーティングフィルムの制}


キトサンの酢酸塩水溶液を調製し，スキーム1に示し た工程で，グリセリンを水洗除去したセロファン上にキ トサンコーティングを行った。すなわちキトサン酶酸塩 办溶液( $1.5 \%$ 酷酸中 $3 \%$ キトサン)をセロファン上にコ ーティングしだ後、濃縮，アルカリ処理，水洗浄，グリ セリン添加，乾燥し，調製した。キトサン盐のコーティ ンク镸度を $3 \%$ よりさくするのは高粘度のため因難で 古った。アルカリ处理は，コート層のキトサン酢酸壏を 進解のキトサンとし，水不溶性とするために必要であっ た。

コーティンタフィルムへの銀の吸着は, $15^{\circ} \mathrm{C} に$ に保っ $た 10^{-2}, 10^{-3}$,及び $10^{-4} \mathrm{M}$ の硝酸銀水溶液 $500 \mathrm{~mL}$ に風乾 1gのコーティンク厚み $5 \mu \mathrm{m}$ のフィムを 5 分間浸漬 することによって行い，フィルムを水洗後，乾燥して実 胗に供した。銀吸着フィルムからの銀の溶出は，20ㄷ

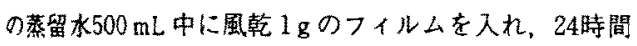
接栈して行った。

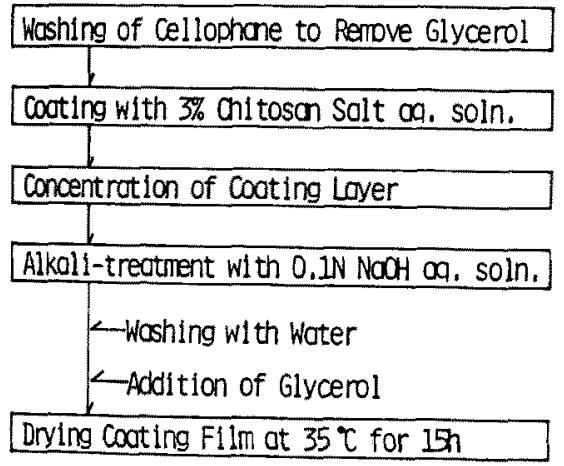

Scheme 1. The procedure of chitosan coating on cel. lophane film.

\section{3 分析 · 濑定法}

フィルムの引張強度はテンシロン型引張試験機を用 い, 試料幅 $15 \mathrm{~mm}$, 引張間隙 $100 \mathrm{~mm}$, 引張速度 10 $\mathrm{mm} / \mathrm{min}$ で測定した。フィルムの湿潤強度はフィルム試 料片を我に湿したのち既定した。コート層の付着強度の 测定は付着面積 $1.5 \mathrm{~cm}^{2}$ とし，JIS-K 5400，8.7に準じ た。フィルムの破裂强度，引裂き強度の測定はそれぞれ IIS-P 8112及U゙8116に従った。

フィルムの透過恝屾可梘光として600 $\mathrm{nm}$, 紫外光とし て300 nm を用いて測定し，この可視光の透過率を透明 度とした。赤外スベクトルはゲルマニウムエレメントを 用いた多重表面反射法により测定した。

フィルム中の銀は JIS-K 0101，16.4に徉って一定風 䑶围のフィルムを质化したのち，6M硝酸で溶解し，
水溶液を原子吸光分析法で定量して算出した。

抗菌性試験は大腸菌 (Escherichia coli IFO 3301)，サ ルモネラ菌(Salmonella typhimurium IFO 14209)，ビブ リオ菌(Vibrio parahaemolyticus IFO 12711), 及びブド ウ球菌 (Staphylococcus aureus IFO 14462)の 4 種の食中 毒菌を日水製薬(株)製のハートインフュージョン赛天平 板培地上に植菌し， $1 \mathrm{~cm}$ 径のフィルムをコート面を下 にして培地上に置き，24-72㭙間 $30^{\circ} \mathrm{C}$ て培養し，菌の 增殖状態を観察した。

\section{3. 結果及び考察}

\section{1 コーティングの際のキトサン溴度の影䈏}

キトサンの酢酸塩水嚓液をセロファンにコーティング した後，濃縮し，アルカリ処理をする。その濃總したキ トサン酢酸塩水溶液の濃度(キトサン濃度と略する)がコ ーティングフィルムの性質に与える影響を検討した。

図1-3にコート㸴 $8 \mu \mathrm{m}$ のフィルムの透明度, 引張強 度と伸び及びコート層の付着強度について調べた結果を 示す。コーティンダフィルムの透明度はキトサン濃度が 高いほど离く，七ロファンと同様の透明なコート厤を得 るには，アルカり処理㷙にキトサンを90\%以上，即ちほ ほ乾燥状熱に濃縮しておく必要があった。3\%キトサン 濃度では，アルカリ処理によってコート触は白濁したゲ ル状キトサンとなり，乾燥後も透明にはならなかった。 これは一旦ゲル化したキトサン層は，そのゲル構造に由

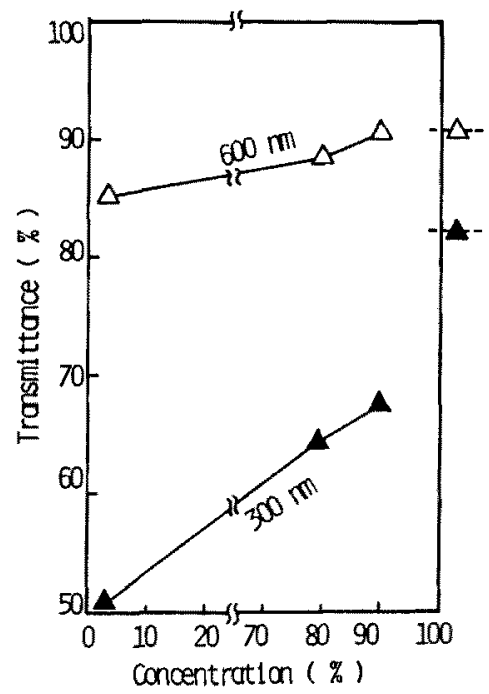

Fig. 1. Effect of concentration of coating layer at alkaljtreatment on transparency of coating film. Temp. at con. centration: $50^{\circ} \mathrm{C}$. Thickness of coating layer: $8 \mu \mathrm{m}$. Note: The symbols on right side refer to transmittances of cellophane film. 


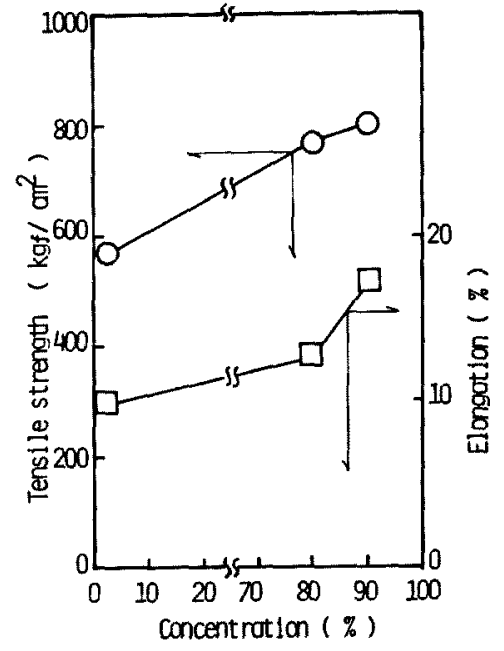

Fig. 2. Effect of concentration of coating layer on tensile strength and elongation of coating film. Temp. at concentration: $50^{\circ} \mathrm{C}$. Thickness of coating layer: $8 \mu \mathrm{m}$.

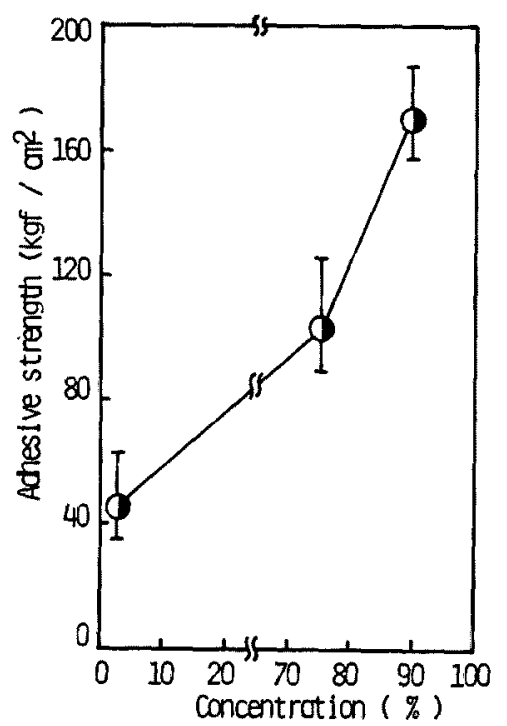

Fig. 3. Effect of concentration of coating layer on adhesive strength between chitosan and cellophane layers. Temp. at concentration: $50^{\circ} \mathrm{C}$. Thickness of coating layer: $8 \mu \mathrm{m}$.

来する不均一相が乾燥後も残存することを意味する。一 方, 紫外光の透過率もコート層の澧縮と共に増大した が，90\%濃度でもセロファンと比較すると低かった。

引張強度は図 2 に示すようにキトサンコート層の濃度 が低いはど低下したが，これも不均一相ではコート層の 強度が上がらないためであろう。また，伸びはキトサン

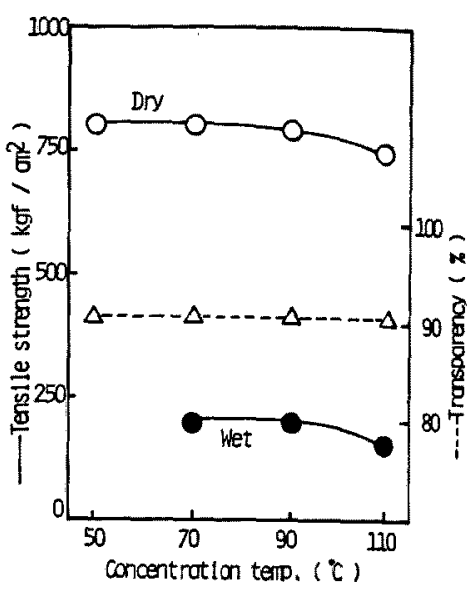

Fig. 4. Effect of temp. at concentration on transparency and tensile strengths of coating film. Thickness of coat. ing layer: $13 \mu \mathrm{m}$. Concentration of layer at alkalitraetment: $90 \%$.

濃度が高いとわずかながら增大した。

キトサンコート層とセロファンとの間の付着强度は图 3 に示したようにキトサン濃度が离くなるとともに增加 し，90\%濃度では170 $\mathrm{kgf} / \mathrm{cm}^{2} の$ 值が得られた。なお， 試験片の作成に用いたエポキシ樹脂とセロファンとの付 着強度は $280 \mathrm{kgf} / \mathrm{cm}^{2}$ であり，キトサンーセロファン間 の付着強度はエポキシ樹脂の $60 \%$ に相当する大きい6の であった。このように、キトサンーセロファン間の付着 強度は適切な条件下では非常に大きいが，不均一相をb つコート層では著しく低下することが分かっだここで 以後，アルカリ処理前のキトサンコート層の瀑度は90\% とした。

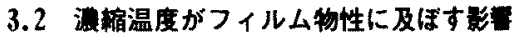

前項でコーティンクのキトサン濃度がフィルムの物性 に影晦することが分がったので，次に㳻縮温度が及はす 影響を検討した。図 4 に透明度と乾燥・湿閏フィルムの 引張強さを示す。透明度に関しては，搌樎温度を $110^{\circ} \mathrm{C}$ まで上げてもセロファンと同程度であった。しかし、引 張強さは濃縮温度が $90^{\circ} \mathrm{C}$ 以上になるとやや低下した。 これは，澧維温度が高いとセロファン自体の強度が低下 するためと思われ，適切な濃縮温度は50-70 ${ }^{\circ} \mathrm{C}$ と分か った。そこで,以後の濃縮操作は50足で行うことにし to

\section{3 コーティングRの本さの朁}

コーティングフィルムの強度等の性質はコート屚に大 きく依存すると思われる。そこで，コート届の厚さとフ イルムの透明度，强度との関係を調へ，罒5に示す。透 


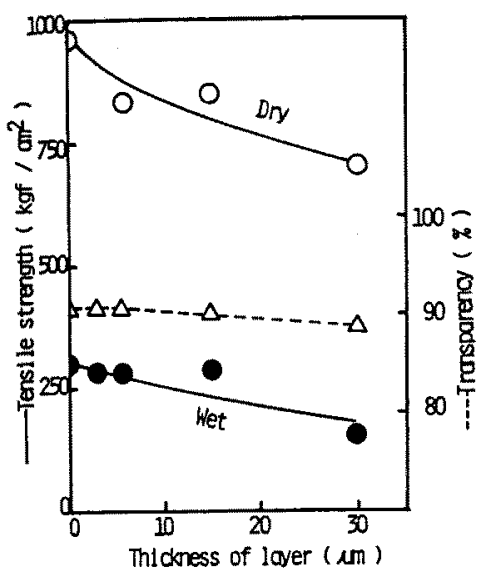

Fig. 5. Effect of thickness of coating layer on trans parency and tensile strengths of coating film. Temp. at concentration: $50^{\circ} \mathrm{C}$, Concentration of layer at alkalitreatment: $90 \%$.

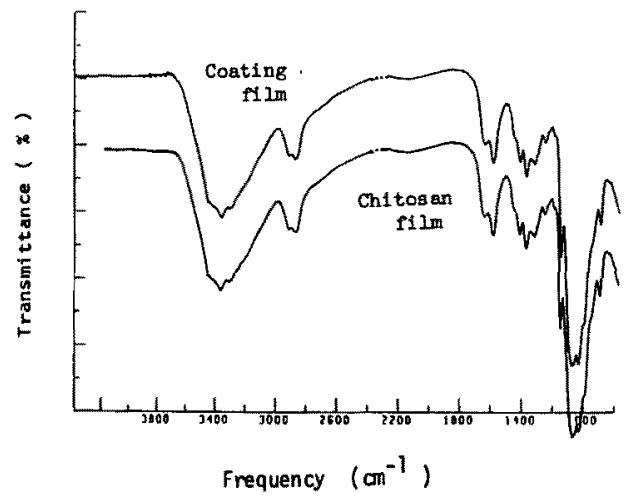

Fig. 6. ATR-IR spectra of chitosan film and chitosan layer of coating film.

明度はコート層厚みが $15 \mu \mathrm{m} て ゙$ も $90 \%$ あった。しかし， 强度はコート層が厚いとむしろ低下し、コーティングに よる强度向上はなかった。コーティングと同様な条件で 作したキトサンフィルムの引張強度は約 $600 \mathrm{kgt} / \mathrm{cm}^{2}$ でセロファンより小さく、キトサンコーティングによる 引張强度への寄与は単に加成的なものと言えよう。

图6には薄いコート層 $(5 \mu \mathrm{m})$ をもつフィルムの赤外 表面反射スペクトルの測定糦果を示すが，コート面のス ペクトルはキトサンのスペクトルと完全に一致して拉 ク， $5 \mu \mathrm{m}$ のコート層でも十分にセロファン面は覆われ ていることが明らかである。また前述したようにコート

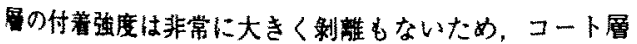
加薄くとも何等支障はないと思われる。
Table 1 Physical Properties of Coating Film

\begin{tabular}{lc}
\hline Tensile strength $\left(\mathrm{kgf} / \mathrm{cm}^{2}\right)$ & 810 \\
Wet tensile strength $\left(\mathrm{kgf} / \mathrm{cm}^{2}\right)$ & 210 \\
Bursting strength $\left(\mathrm{kgf} / \mathrm{cm}^{2}\right)$ & 3.4 \\
Tearing strength $(\mathrm{gf})$ & Direction av. 4.8 \\
Elongation $(\%)$ & 18 \\
Transparency $(\%)$ & 91 \\
Water vapor transmission rate $\left(\mathrm{g} / \mathrm{m}^{2} * 24 \mathrm{~h}\right)$ & 2470 \\
\hline
\end{tabular}

Note: Coating concentration: $90 \%$. Temp. at concentration: $50^{\circ} \mathrm{C}$. Film thickness: ca. $25 \mu \mathrm{m}$ (Coating layer: 5 $\mu \mathrm{m}$ thick).

キトサンの浱度約 $90 \%$ となるよう $50{ }^{\circ} \mathrm{C}$ で濃樎, アル

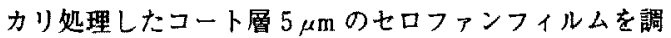
製し，その性質を表 1 に示す。この条件下で測定する と，セロファンの特長である透明度や透湿性を損なわ ず，良好にコーティンダできることが分かった。なお， コーティングフィルムの強度は全体的に市販七ロファン よりも低かったが，これはセロファンに洗净・濃縮・ア ルカリ処理・乾燥などの处理を行ったためである。

このように，本実験のキトサンコーティングのアルカ り処理に伴う濃縮や乾燥を行う工程は複雑でもあり，七 ロファン母材の强度も低下する。そこでアルカリ处理の 不要なコーティング工程については，今後さらに檢討を 進める予定である。

\section{4 銀吸着したコーティングフィルムの抗菌性}

さて、キトサンコーティングによるセロファンフィル ムの機能開発のひとつとして抗菌性の付与が考えられ る。

最近，銀を含有させたぜオライトを含む抗菌性包装用 フィルムを製造する試みが見られるように[5-7]，銀イ オンは人体への害が少なく，強力な抗菌作用を示す 〔7〕。トサンはそれ自身でも抗菌性があるとされるが (8-11]，銀イオンなどの重金属を吸着して安定なキレー 卜を容易に形成する性質〔12〕もあり，キトサンコート 層は銀を担持させるのに適している。そこで，前述の条

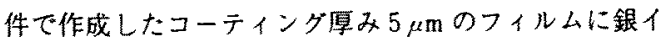
オンを $1500,4800,18000 \mathrm{ppm}$ 吸着させ，その抗菌性を 検討した。

銀を吸着させた直後はフィルムは無色だが，銀浱度が 高い場合岵露光によって速やかに薄紫色を呈した。しか し，フィルムの銀濃度が $4800 \mathrm{ppm}$ 以下ではほとんど呈 色せず，透明度も低下しなかった。

\subsection{1 コーティングフィルムの抗賟性}

大腸菌，サルモネラ菌，ビブリオ菌，ブドウ球菌に対 するセロフォン、銀未吸着コーティングフィルム及び銀 
吸着コーティングフィルム(銀濃度 $1500 ， 4800 ， 18000$ ppm）の抗菌性を検討した。銀吸着させたフィルムは露 光したものを用いた。なおこれらのフィルムは湿った状 態では酸素透過性があり，これらの通性嫌気性菌はフィ

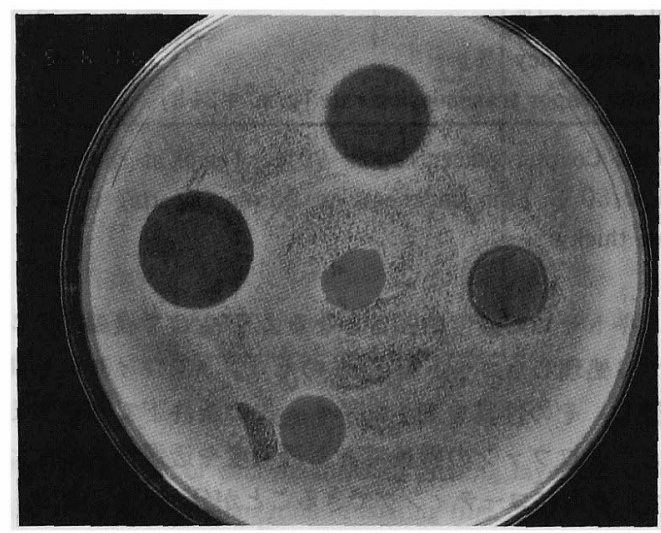

Photo 1. Observation of anti-microbial test of coating film.

Center: cellophane,

Lower: cellophane coated with chitosan, Absorbed Ag 0 ppm.

Right: cellophane coated with chitosan, Absorbed Ag $1500 \mathrm{ppm}$,

Upper: cellophane coated with chitosan, Absorbed Ag $4800 \mathrm{ppm}$,

Left: cellophane coated with chitosan, Absorbed Ag $18000 \mathrm{ppm}$.
ルム接触面下の環境でも十分增殖し得る。

写真 1 に, ブドウ球菌の24時間後の增殖状態を示す。 銀吸着コーティングフィルムの場合は接触面に菌がほと んど増殖せず，また溶出透明斑が生じて明らかに抗菌性 が認められる。一方，セロファンと銀末吸着コーティン グフィルムでは溶出透明斑はなく，フィルムに接触した 面にも菌が多く増殖している。

それぞれのフィルムの 4 種の菌に対する抗菌性につい て, 植菌48時間後のフィルム接触面の菌增殖状態及びフ イルム外部の透明斑の大きさを調べて表 2 に示す。セロ ファンでは，接触面でも透明斑に関しても抗菌性は全く なかった。銀未吸着コーティングフィルムにも透明斑は なく, 接触面には 4 種の菌とも増殖しており, 抗菌性が なかった。

溶解したキトサン塩は、フザリウム等の植物病原菌類 や食中瑇菌に対して抗菌性を示すとされる[9-11)。し かし，キトサンコーティングフィルムを用いた本実験で は 4 種の食中毒菌に対する抗菌性は認められなかった。 鶴谷ら [13] はキトサンフィルムを調製して大腸菌とフ ドウ球菌に対する抗菌性を調べ，溶出性の抗菌性はな く，接触的抗菌性は酢酸程型キトサンフィルムの場合た けに認められると報告している。本実験のキトサンコー ティングフィルムには接触的抗菌性も認められなかった が，これはコート層がアルカリ処理・水洗によって遊 型キトサンになっているためと思われる。

一方，銀吸着フィルムは表 2 に示すように, フィルム の銀濃度が一番低い $1500 \mathrm{ppm}$ でも全ての菌に対して溶 出透明斑が生じ，十分な抗菌性が認められた。この抗菌

Table 2 Anti-microbial Test for Chitosan Coating Film Absorbing Ag

\begin{tabular}{lccccc}
\hline Ag content (ppm) & Cellophane & Coating & Coating & Coating & Coating \\
& 0 & 0 & 1500 & 4800 & 18000 \\
\hline $\begin{array}{l}\text { Escherichia } \\
\text { Growth under film }\end{array}$ & ++ & ++ & +- & - & - \\
$\quad$ Inhibition zone $(\mathrm{mm})$ & 0 & 0 & 0.4 & 1.5 & 1.7 \\
Staphylococcus & & & & - & - \\
$\quad$ Growth under film & ++ & ++ & +- & 2.7 & 3.0 \\
Inhibition zone $(\mathrm{mm})$ & 0 & 0 & 0.9 & & - \\
Salmonella & & & & - & 3.0 \\
Growth under film & ++ & ++ & - & 2.7 & - \\
Inhibition zone $(\mathrm{mm})$ & 0 & 0 & 0.9 & - & 1.2 \\
Vibrio & & & & & \\
Growth under film & ++ & ++ & +- & 0.7 & \\
Inhibition zone $(\mathrm{mm})$ & 0 & 0 & 0.2 & & \\
\hline
\end{tabular}

Note: Observation was carried out $48 \mathrm{~h}$ after inoculation. 
Table 3 Release of $\mathrm{Ag}$ from Coating Film to Distilled Water

\begin{tabular}{cc}
\hline $\begin{array}{c}\text { Ag concentration } \\
\text { of film (ppm) }\end{array}$ & \multicolumn{2}{c}{ Loss of Ag } \\
from film \\
$(\%)$ \\
\hline 0 & - \\
1500 & 3.3 \\
4800 & 10.9 \\
18000 & 22.2 \\
\hline
\end{tabular}

Note: $1 \mathrm{~g}$ film $/ 500 \mathrm{~mL}$ distilled water; Stirring for $24 \mathrm{~h}$ at $20^{\circ} \mathrm{C}$.

性は72時間後も継続していた。

\section{4 .2 フィルムからの銀の容出}

平板培地での実験で溶出透明斑があったが，これは銀 が培地に溶出しているためと考えられる。そこで蒸留水 孝用い，銀のフィルムから水への溶出について検討し た。表了に示すようにフィルムからの銀の溶出率は、フ イルムの銀浱度を低くすれば小さくなることが分かっ た。これはキトサンの銀イオンに対する強い吸着性 [12]，高いキレート平衡定数によると推定される。銀濃 度 $1500 \mathrm{ppm}$ のフィルムでは水中に溶出した銀の濃度は この実験条件下で0.1 ppmであり，アメリカの飲料水質 基準の0.05 ppm〔7]と比べて 2 倍高かった。しかし， フィルム中の銀濃度を低くすれば銀の溶出をさらに抑制 できるためここのコーティングフィルムは抗菌性包装用 として興味ある素材と言えよう。

\section{4. 䊅 論}

キトサンをセロファンにコーティングしたフィルム は，引張，引裂き等の強度改善効果はなかったが，七ロ ファンの透明度や透湿性を損なうことなく良好なコート 層が得られた。セロファンとキトサンコート層との間の
付着強度はアルカリ処理前のキトサン濃度が高いはど強 く, $90 \%$ 濃度では $170 \mathrm{kgf} / \mathrm{cm}^{2} に$ 達した。

大晹菌，サルモネラ菌，ビブリオ菌，ブドウ球菌に対 するフィルムの抗菌性はキトサンコーティングだけでは 諗められなかったが、コート層に銀イオンを吸着させる ことによりフィルムの銀濃度 $1500 \mathrm{ppm}$ で十分な抗菌性 を付与できた。

\section{引用文献}

1. K. Sakurai, K. Kobayashi, and T. Takahashi, Sen $\ddot{i}$ Gakkaishi, 45(1). 22.26 (1989)

2. T. Seo, S. Hagura, T. Kanbara, and T. Iijima, J. Appl. Polym. Sci., 37, 3011-3027 (1989)

3. キチン，キトサン研究会編，「キチン、キトサンの 応用」，技報堂，p 104（1990）

4. G. G. Allan and Y. Hirabayashi, Cellulose Chem. Technol., 18, 83.87 (1984)

5. 离橋務, FOOD PACKAGING, 1985 (5)，83-86 (1989)

6. 落合信哉, 合成樹脂, $35(10) ， 17-22(1989)$

7. 工業技術会編 - 発行，「食品の鮮度保持と保存技術 II], P 213 (1989)

8. C. R. Allan and L. A. Hadwiger, Exp. Mycol., 3, 285 (1979)

9. 内田 泰, 井爪正人, 三宮正博, 大宝 明, 農芸化 学会年次大会講演要旨集, p 547 (1987)

10. 内田泰, フードケミカル, 1988(2), 22-29 (1988)

11. D. F. Kendra and L. A. Hadwiger, Exp. Mycol., 8, 276 (1984)

12. T. Koshijima, R. Tanaka. E. Muraki, A. Yamada, and F. Yaku, Cellulose Chem. Technol., 7, 197 (1973)

13. 鶴谷勝正, 吉川 斌, 田島純一, 石井美治, 紻学 誌, 47(4)，190-197（1991） 